\title{
THE MADRE DELLA CONSOLAZIONE ICON IN THE BRITISH MUSEUM: POST-BYZANTINE PAINTING, PAINTERS AND SOCIETY ON CRETE*
}

\author{
With two plates
}

A small portable icon $(350 \times 270 \mathrm{~mm})$, now in the British Museum, Department of Medieval and Later Antiquities (reg. No. 1994, 1-2, 6), depicts the Virgin and Child (fig. 1). It is painted on a single panel of pine wood, apparently without fabric between the ground and wood support. The icon was bequeathed by Guy Holford Dixon JP, who bought it from the Temple Gallery. A label on the back, attached when the icon was in the possession of the Temple Gallery, describes it as being Russian of the sixteenth century. In a preliminary Museum catalogue, however, the origin was given as Italy or Crete and the date as seventeenth century. ${ }^{1}$ The truth about the origin and the dating of the icon, as we shall see, lies in the middle: I will argue that it is from Crete and of the sixteenth century.

The Virgin is depicted half-length, holding the Christ-Child in her right arm while touching His left leg gently with her left hand. Her head is tilted towards the Child, although she does not look at Him. She wears a green garment and a purple maphorion on top, which bears pseudo-kufic decoration on the edges; decorative motives are also visible on the garment's collar and left sleeve. The maphorion is held together in front of the Virgin's chest with a golden brooch, which apparently used to have decoration, now lost. Underneath the maphorion, a kerchief - a white, gauze-like piece of cloth with stylized edges - may be discerned. The Christ-Child wears a dark-green chiton, with star-shaped decorative motives, on top of a diaphanous garment visible on His upper right arm. Over this is a red himation with golden highlights. He blesses with His right hand and holds an open scroll inscribed in Greek in His left. The text reads: חNEYMA

* I would like to thank Mr C. Entwistle of the British Museum, Department of Medieval and Later Antiquities, for allowing me to publish this icon. I would also like to thank Dr Leslie Brubaker and Dr Maria Vassilaki, for reading the paper and for their valuable comments.

1 This list was revised in 1997 by the author; our icon appears as no. 24 . 
KYPIOY EП EME, OY EINEKEN EXPI $\Sigma$ E ME (The spirit of the Lord is upon me, because he hath anointed me), a passage commonly found in representations of the Virgin and Child that derives from Luke 4, 18, which itself repeats Isaiah $61,1 .{ }^{2}$ The background is gold, but has largely flaked off, while many cracks and a few scratches are visible on its surface, but fortunately have not caused serious damage. Two inscribed circles, one inside the other, form each halo. On the background there were capital letters in red, faded but still discernable in places: $\Theta Y$ on the Virgin's left hand side, IC XC above Christ's head. Most probably on the Virgin's right hand side we had the letters MHP, identifying her as the MHTHP @EOY (Mother of God). The undertone of the flesh is dark.

The type of the Virgin depicted in our icon is known as the Madre della Consolazione. The type is named after an Italian frescoed icon of the fifteenth century, found in the church of Santa Maria della Consolazione in Rome. ${ }^{3}$ The characteristic features of the Madre della Consolazione include the placement of the Christ-Child in a position in which His head is turned towards the opposite direction to that of His legs, the placement of the Virgin's hand on the Child's knee, the patterns on the Child's chiton which imitate decorative motives found in Italian fabrics and painting, the gold band with the pseudo-kufic decoration along the edges of the Virgin's maphorion, the brooch which holds it together in front of her chest, and the kerchief with its stylized edges which she wears on her head underneath her maphorion. ${ }^{4}$ The open scroll with the Greek inscription which the Child

2 M. Chatzidakis, Les débuts de l'École Crétoise et la question de l'École dite Italo-

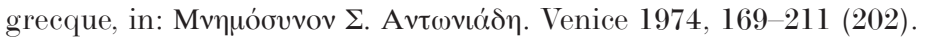

${ }^{3}$ M. Dejonghe, Orbis Marianus. Les Madonnes Couronnées à travers le monde. I. Les Madonnes Couronnées de Rome. Paris 1967, 50 (fig. 8), 51-52; P. Fernado da Riese, S. Maria della Consolazione (Le Chiese di Roma Illustrate 98). Rome 1968, 82-85, fig. 25. See also N.Chatzidakis, Icons of the Cretan School $\left(15^{\text {th }}-16^{\text {th }}\right.$ Century), Exhibition Cata-

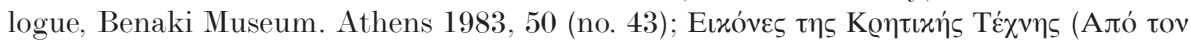

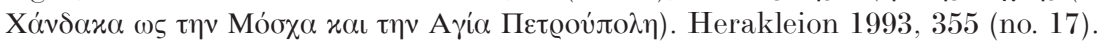

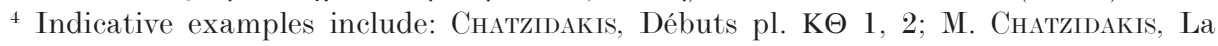
peinture des 'Madonneri' ou 'Vénéto-Crétoise' et sa destination, in: Venezia Centro di Mediazione tra Oriente e Occidente (Secoli XV-XVI). Aspetti e Problemi, Vol. II (eds. H. G. Beck, M. Manousakas, A. Pertusi). Florence 1977, 673-690 (fig. 48); Chatztidakis, Icons of the Cretan School 50 (nos. 43, 44); M. Acheimastou-Potamianou (ed.), From Byzantium to El Greco. Greek Frescoes and Icons. Royal Academy of Arts, London

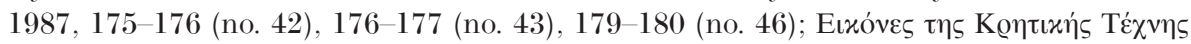
355 (no. 17); D. Buckton (ed.), Byzantium. Treasures of Byzantine Art and Culture from the British Collections. British Museum, London 1994, 22, fig. 2. For examples of

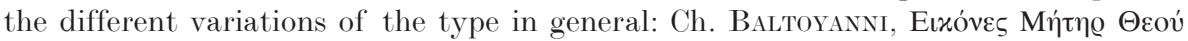

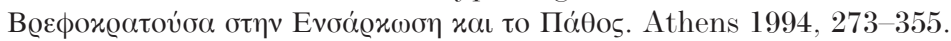


holds in our icon, without being exceptional as other examples demonstrate, ${ }^{5}$ is found less frequently than a sphere or a closed scroll.

It is generally accepted that it was the famous post-Byzantine Cretan painter Nikolaos Zafuris and his workshop who introduced and spread the type in Crete in the late fifteenth century. ${ }^{6}$ Here it became one of the most popular types of the Virgin and Child, and was widely distributed until the seventeenth century, ${ }^{7}$ perhaps because it met the requirements of both the Orthodox and Catholic faithful on and off the island. Zafuris was a resident of Candia, known today as Herakleion, the capital of Crete. He is mentioned in a number of Venetian documents between the years 1487 and 1501 ; by the latter year he was already dead. ${ }^{8}$ His widow is mentioned in two further documents dated 1507 and 1510, while the painter's will which was lost and then rediscovered in the year 1537 is the subject of a document of that date. ${ }^{9}$ Seven signed works have survived, ${ }^{10}$ while an eighth, known to us through three documents, is lost. ${ }^{11}$ Three of the signed works depict

${ }_{5}^{5}$ Buckton (ed.), Byzantium 22, fig. 2. According to Chatzidakis, Débuts 201-202, n. 111, the open scroll points to an influence from a Virgin by Barnaba da Modena, as depicted, for example, in A. Venturi, Storia dell' Arte Italiana. V. La Pittura del Trecento e le sue Origini. Milan 1907, fig. 748.

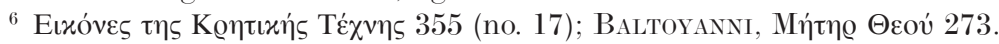

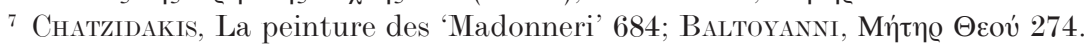

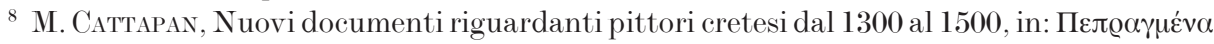

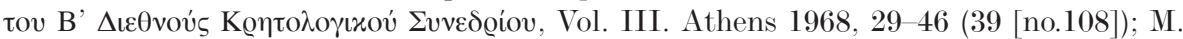



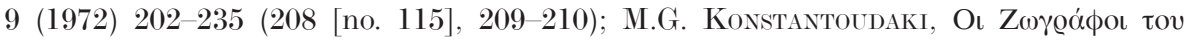

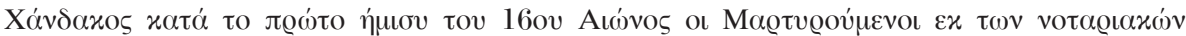

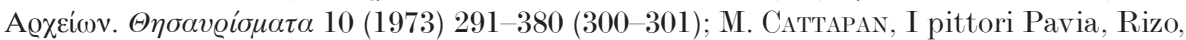

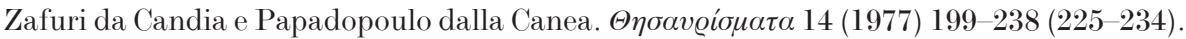

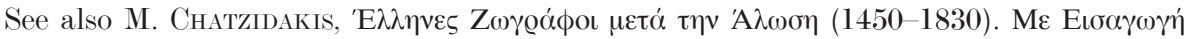

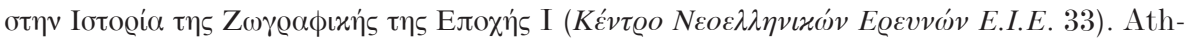

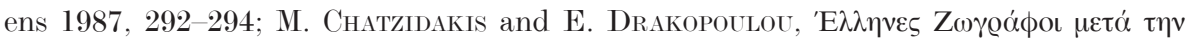

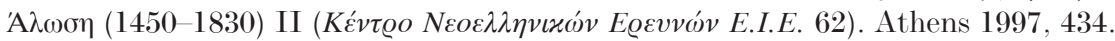

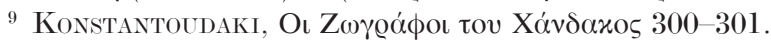

${ }^{10}$ Recently two icons were discovered with the painter's signature: E. Haustein-Bartsch, Eine neuentdeckte Ikone der 'Madre della Consolazione' von Nikolaos Tzafoures. DChAE

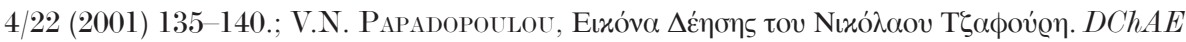
$4 / 22$ (2001) 261-270. The icon published by the latter author is the only known, so far, painted by Zafuris in a Byzantine manner.

11 Cattapan, Nuovi elenchi 209-210. The lost work was a pala d'altare and involved the collaboration of three artists: Zafuris, another painter called Georgios Vlasto, and a sculptor, Nikolaos Barbarigo. Zafuris was commissioned to paint twenty-three figures. The recipient of the impressive work was Giovanni Nani, the Venetian governor of Nauplio in the Peloponese. Zafuris' high payment confirms his status as a reputable

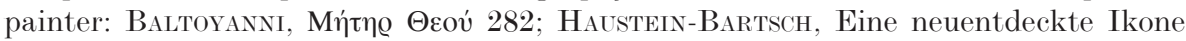

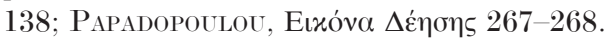


the Madre della Consolazione: one is in the Kanellopoulos collection in Athens, dated most probably in the year 1500 (fig. 2), ${ }^{12}$ the second is in a private collection in Trieste, ${ }^{13}$ while the recently-discovered third is in a private collection in the Netherlands. ${ }^{14}$

The generally accepted view that the Madre della Consolazione is a western (i.e. Italian) 'creation' was questioned by Baltoyanni. ${ }^{15}$ She argued that the type is in its essence Byzantine, closely connected to the Virgin חONO $\Lambda$ YTPIA (delivering from pain) first encountered in a fresco in the church of the Taxiarchai at Sachnoe, dated $1390 / 91,{ }^{16}$ that depicts a standing, full length Virgin and Child. ${ }^{17}$ Baltoyanni also pointed to the Byzantine origin of some of the isolated characteristics of the type, such as the gentle touch of the knee of the Child by the Virgin, His diaphanous undergarment, His elaborate chiton, and the open scroll in His hand..$^{18}$ It cannot be denied that the touch of the Child's knee, a manifestation of the 'motherly' nature of the Virgin, ${ }^{19}$ is rooted in Byzantine art. ${ }^{20}$ The same is true for the diaphanous undergarment of the Child, which Mouriki has demonstrated found its way into western art from Byzantium. ${ }^{21}$ However, the various decorative patterns seen on the Child's chiton in representations of the Madre della Consolazione are always inspired by fabrics and/or paintings of the Italian Trecento. ${ }^{22}$ This is certainly true for the decorative pat-

12 Acheimastou-Potamianou, (ed.), From Byzantium to El Greco 175-176 (no. 42); Bat-

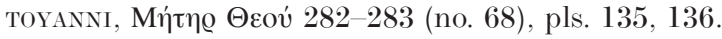

13 M.Bianco-Fionin, Nicola Zafuri, Cretese dal Quattrocento, e una sua inedita 'Madonna'. Arte Veneta 37 (1983) 164-169.

${ }^{14}$ Haustein-Bartsch, Eine neuentdeckte Ikone.

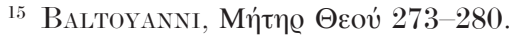

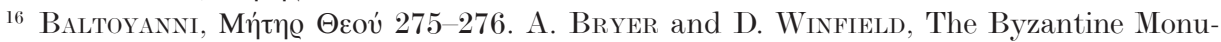
ments and Topography of Pontos (DOS 20). Washington, D.C. 1985, 286-289 (no. 25), suggested the 1390/91 dating of the church, as opposed to 1622 given by Talbot Rice.

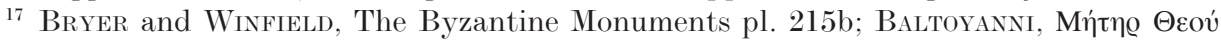
fig. 18.

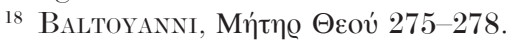

19 I. Kalavrezou, The Maternal side of the Virgin, in: Mother of God. Presentations of the Virgin in Byzantine Art. Benaki Museum 20 October 2000-20 January 2001 (ed. M. Vassilaki). Athens 2000, 41-45. See also I. Kalavrezou, Images of the Mother: When the Virgin Mary became Meter Theou. DOP 44 (1990) 165-170.

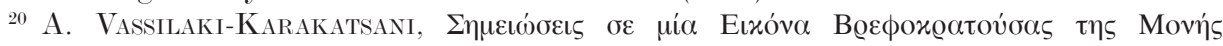

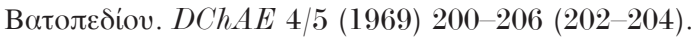

${ }^{21}$ D. Mouriki, Variants of the Hodegetria on two thirteenth-century Sinai Icons. CahArch 39 (1991) 153-182 (165-170).

${ }^{22}$ I would like to thank Dr Rembrandt Duits - whose Ph.D thesis is on Gold Brocade in Renaissance Painting. An Iconography of the Riches. University of Utrecht 2001 - for discussing at length this point with me. 
tern seen on the Child's chiton in the British Museum icon (fig. 1): similar motives, created by the repetition of simple star-shaped patterns, as seen here, can be found in a number of fourteenth-century Italian examples, from textiles and paintings. ${ }^{23}$ This pattern decorates the chiton of the Child also in other Madre della Consolazione icons, as seen, for example, on a panel from the church of Hagia Aikaterini on Patmos, dated around 1500, another in Berlin, dated at the end of the fifteenth century, and on two sixteenth-century icons, one in the Museum of Ravenna, the other in Syracuse. ${ }^{24}$ Furthermore, two elements of the Virgin's attire are typically western. The one is the brooch that fastens her maphorion in front of her chest. Brooches were a common part of western attire, used by both men and women to fastened cloaks and mantles, often in a manner similar to the one seen in the Madre della Consolazione icons. ${ }^{25}$ Brooches are also part of the ecclesiastical garments of the western church, used to fastened the pluvial (pluviale, the priest's cope), but they were never really needed in the respective attire of the Orthodox clergy. ${ }^{26}$ The other western detail is her kerchief, visible beneath the maphorion, which never forms part of the Virgin's head cover in Byzantine art; however, is used amply in the representations of the Virgin in Italian art. ${ }^{27}$

${ }^{23}$ The star-shaped patterns can be enclosed within circles or other geometric forms. See B. KLEsse, Seidenstoffe in der italienischen Malerei des 14.Jahrhunderts (Schriften der Abegg-Stiftung Bern 1). Bern 1967, 71 (fig. 64), 119 (fig. 157), 132 (fig. 180, right part; same concept, with the pattern enclosed within circles), 132 (pl. XII; enclosed within geometric forms), 144 (fig. 191, angel second from the top, to the right), 190 (no. 50; enclosed within geometric forms and combined with other patterns), 242 (no. 132; enclosed within diamond-shaped forms and combined with other patterns), 312 (no. 232, enclosed within diamond-shaped forms and combined with birds), 349 (no. 292, combined with bird motives).

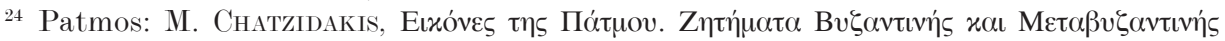

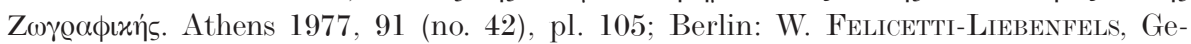
schichte der byzantinischen Ikonenmalerei. Von ihren Anfängen bis zum Ausklange unter Berücksichtigung der Maniera Greca und der Italo-Byzantinischen Schule. Olten-Lausanne 1956, 114; Ravenna: G. Pavan, Icone dalla collezione del Museo Nazionale di Ravenna. Ravenna 1979, 40 (no. 33) and 43 (coloured); Syracuse: Siracusa Bizantina. Immagine dell' Invisible. Mostra di Antiche Icone Siciliane a cura dell' Associazone Russia Cristiana «San Vladimir» Siracusa. Syracuse 1989, 46 (pl. 16).

${ }^{25}$ R. W. Lightbown, Medieval European Jewellery. With a Catalogue of the Collection in the Victoria \& Albert. London 1992, 136-187, 491-500. Some of the brooches were richly elaborated: ibid., 424, pl. 27.

${ }^{26}$ J. Braun, Die liturgische Gewandung im Occident und Orient nach Ursprung und Entwicklung, Verwendung und Symbolik. Freiburg im Breisgau 1907, 306-358, and 144, fig. 58 (priests standing to the left), 266, fig. 124 (priest standing to the left).

${ }^{27}$ See, for example, the Madonna del Bordone, by Coppo di Marcovaldo, dated 1261, and the Virgin and Child by Guido da Siena, dated 1275/80(?): J. WhiтE, Art and Architec- 
Returning to the Sachnoe fresco, which is Baltoyanni's main argument for the Byzantine origin of the Madre della Consolazione type, we see that the Child turns and directs His blessing gesture to the left, where Saint John Prodromos O BAZE $\Lambda \Omega(\mathrm{NOC}$ ) (of Vazelon) is depicted. John holds an open scroll with the text I $\triangle E$ O AMNOC TOY $\Theta E O Y$ O AIPSN THN AMAPTIAN TOY KOCMOY (Behold the Lamb of God, which taketh away the sin of the world). This text is closely associated with John the Baptist and the Baptism of Christ, since according to the Gospel of John $(1,29)$, the Baptist greeted Christ with these words. Furthermore, the Baptism is closely associated with Christ's death on the cross and resurrection (Romans 6, 3-23). Christ Himself referred to His Passion as Baptism (Matthew 20, 22-23; Luke 12, 50). ${ }^{28}$ It seems reasonable, therefore, to suggest that in this particular fresco, Saint John is an integral part of the composition with direct references to Christ's Sacrifice, a point accepted by Baltoyanni. ${ }^{29}$ However, in some of the variations of the Madre della Consolazione type, where one or more saints are included, the Child, unlike in the Sachnoe fresco, is not in direct contact with them. ${ }^{30}$ In short, none of the post-Byzantine Madre della Consolazione icons reproduces exactly the Virgin ПONO $\Lambda$ YTPIA,${ }^{31}$ and the derivation of the former type directly from Byzantine art is not justified.

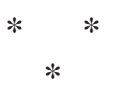

ture in Italy 1250-1400. New Haven-London 1993, 164, fig. 91 and 170, fig. 96 respectively.

28 A. Lymberopoulou, The Fourteenth-Century Church of the Archangel Michael at Kavalariana, Crete. Department of Byzantine, Ottoman and Modern Greek Studies, University of Birmingham 2001 (unpublished Ph.D. thesis), 71-78.

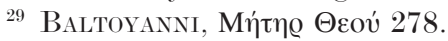

${ }^{30}$ See, for example, Pavan, Icone di Ravenna 50 (nos. 55, 57), 51 (no. 59 ), 52 (no. 60); 53 (no. 65), 54 (no. 66); 55 (no. 68); P. Angiolini-Martineldi, Le Icone della Collezione Classense di Ravenna (Rapporti della Sopritendenza per $i$ beni artistici e storici per le province di Bologna, Ferrara, Forli e Ravenna 39), Bologna 1982, 46, 149 (no. 65), 135 (no. 55), 140-141 (no. 57), 143 (no. 59), 144 (no. 60), 152 (no. 68); Аснeimastou-Potamianou (ed.), From Byzantium to El Greco 179-180 (no. 46); N. Chatzidakis, Da Candia a Venezia. Icone greche in Italia XV-XVI secolo, Museo Correr, Venezia 17 Settembre30 Ottobre 1993 (Venezia quasi alterum Byzantium). Athens 1993, 132 (no. 31), fig. 31.

${ }^{31}$ Th. Gouma-Peterson, Crete, Venice, the 'Madonneri' and a Creto-Venetian Icon in the Allen Art Museum. Allen Memorial Art Museum Bulletin 25/2 (1968) 52-86 (59-60 and n. 20), reaches similar conclusions regarding the connection of the post-Byzantine type of the Virgin of the Passion and the fresco in the monastery of Arakos at Cyprus, dated 1192. 
Since the British Museum icon is neither signed nor dated, a stylistic analysis is needed in order to determine its chronological placement. Two icons will provide the frame within which our icon will be examined: one is the Madre della Consolazione icon by Zafuris (fig. 2), which usually provides either the terminus ante or post quem. The other is by another well-known post-Byzantine Cretan painter of the seventeenth century, Victor, situated today in the church of Hagioi Theodoroi, on Corfu, which, according to Vokotopoulos, copies fifteenth-century examples (fig. 3). ${ }^{32}$

Zafuris' Virgin and Child are characterized by a 'dreamy' state of being: neither is engaged with the viewer and both are rather distant, while the Virgin's face has a 'sad' expression (fig. 2). The Virgin has an impressive presence with her bulky, 'giottesque' appearance. For both figures, the eyebrows are thin and well defined, the eyes are narrow and almondshaped, the nose is long and thin with bulging left nostril, and the lips are full and fleshy with the upper lip shaped in a wide M. Christ's left ear is formed by two curvy lines, of which the outer one is very thick. The Virgin's left hand is swollen with long, thin but wooden fingers. The way her right hand supports the Child is characteristic of many Cretan icons of the type, and it might suggest the use of this icon as a prototype: the palm is positioned almost at a right angle in regards to her arm and creates an artificial and unnatural position for it. The undertone of the flesh is of soft wheat-colour. The haloes are formed simply, with just two concentric circles one inside the other. Christ's red himation with its gold striations does not describe His body underneath, apart from a hint in the area around His right thigh and knee, where the gold lines are dense. The Virgin's kerchief has stylized folds that finish at sharp edges. The folds of her maphorion form round loops marked with soft, black lines in their dark sides. To the right, in the area of her upper arm, there is a heart-shaped fold, while in the area of her elbow two egg-shaped folds, one inside the other.

Victor's Virgin, although it retains the 'giottesque' appearance, has lost the 'sad' expression: her face is softer, which eliminates the gravity of the Madre della Consolazione by Zafuris (fig. 3). Furthermore, both figures are engaged with the viewer. Their eyebrows are thick, the eyes big and almond-shaped with well-defined lines underneath that create pouches, the

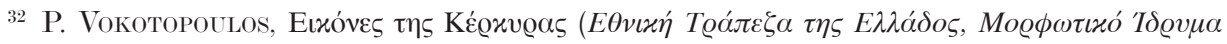

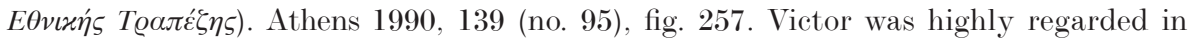
seventeenth-century Cretan icon production, albeit some of his clients did complain

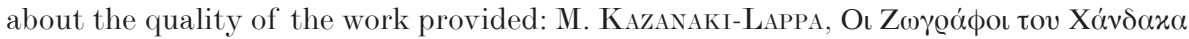

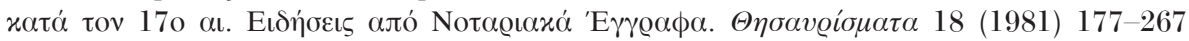

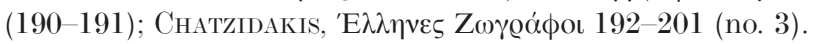


noses are long and thick with the visible left nostrils large and bulging, while the lips retain the shape of $\mathrm{M}$ in, however, a wider formation. Christ's left ear has the shape of sickle with a rounded earlobe. The Virgin displays the same wooden hands but with thicker fingers, and the same angle in her right hand that supports the Child. The undertone of the flesh is soft and bright. The haloes are also formed in the same, simple way seen in the Zafuri's icon, while Christ's himation does not describe His body apart, again, from the area around His right thigh. The Virgin's kerchief has lost most of its folds and those remaining are not stylized and do not finish at sharp edges. The folds on her maphorion are stiff rather than soft, and their dark sides are marked with very thick black lines. The heart-shaped fold in her upper arm has disappeared. The folds on her head look like mere partitions of the garment, albeit thick ones.

An examination of the Madre della Consolazione in the British Museum reveals that the icon is stylistically closer to the one created by Zafuris (fig. 1). While the Virgin does not have the bulky appearance of either Zafuri's or Victor's version, she retains the 'sad' expression of Zafuri's example, and both she and Christ retain the aloof, distant look. The eyebrows are slightly thicker than Zafuris' and are well-defined, but they are not as thick as Victor's. The rest of the facial characteristics are also closer to the Zafuris icon: the eyes are narrow and almond-shaped, the noses are long and thin with bulging left nostrils and a bulging tip for Christ, the lips are formed in a wide M-shape, and Christ's left ear has a thick outline. The Virgin's fingers are long, thin and wooden, while her right hand is placed in the familiar angle. The undertone of the flesh is also wheat-coloured; it is, however, slightly darker than Zafuris'. The haloes are formed in the same, simple way as in the previous two icons, and Christ's chiton does not describe His body underneath, although the concentration of gold striations in the area around His right thigh is higher. The Virgin's kerchief retains its folds, which are, however, softer than Zafuris' but still finishing with sharp edges. Her maphorion displays folds formed in a very similar way to the ones seen in Zafuris' icon, with round loops, especially the heart-shaped and the egg-shaped (only one for our icon) folds in the area of her upper arm and elbow respectively, however the black lines on the dark sides are thicker, but not as thick as the ones by Victor. Similar soft folds characterize the part of maphorion placed on her head. Therefore, the British Museum icon should be dated closer to ca. 1500 than to the seventeenth century. In fact, the 'sad', distant expression of the Virgin, the sharper definition of the facial characteristics, the darker wheat-coloured undertone of the flesh, the harder dark lines on the inside of the folds, all of which are found in our icon, stylistically characterize Madre della Con- 
solazione panels that can be dated in the first half of the sixteenth century. $^{33}$

Due to the lack of evidence, it would be futile to attempt an association between the unidentified painter of our icon and Zafuris' circle. When compared to the master's work, the British Museum icon can be characterized as of lesser quality, but it nonetheless displays elements of skilled craftsmanship, such as the well-defined facial characteristics of both the Virgin and Child, the soft, flowing folds on the Virgin's maphorion, and the rich gold striations on the Child's himation. The controversial and vague term 'madonnero', which usually describes inferior painters of religious works (i.e. Madonnas), cannot be used for our painter, and, in any case, as Chatzidakis has suggested, it should be abandoned. ${ }^{34}$ In all probability the anonymous artist used either a good prototype, or more likely, given their wide use among post-Byzantine painters, an anthibolo (working drawing, pre-prepared sketch). The anthibola enabled painters to reproduce popular types swiftly, and, as a consequence, to deal quickly with commissions..$^{35}$ Not surprisingly, painters considered them valuable possessions. ${ }^{36}$ We know from documents that the anthibola were passed from the hands of one painter to another or to their apprentices. For example, the will of the famous fifteenth-century Cretan painter Angelos Akotantos left his anthibola to his brother Ioannis, who in his turn sold them to another famous Cretan painter, Andreas Ritzos. ${ }^{37}$ The close similarities between the two icons depicting Christ enthroned, the one on Zakynthos painted by Angelos,

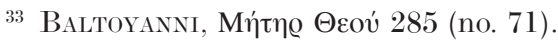

${ }^{34}$ Gouma-Peterson, Creto-Venetian Icon 68-76, summarizes the different opinions on the definition of the term; Chatzidakis, Débuts 208, n. 129; M. Chatzidakis, Essai sur l'école dite 'italogrecque' précédé d' une note sur les rapports de l'art vénitien avec l'art crétois jusqu'à 1500, in: Venezia e il Levante fino al secolo XV, Vol. II (Civiltà Veneziana Studi 27) (ed. A.Pertusi). Florence 1974, 69-124 (118, n.2); Chatzidakis, La peinture des 'Madonneri' 674 .

35 See infra, 254-255.

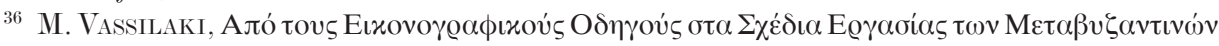

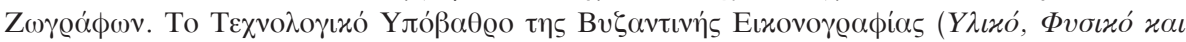

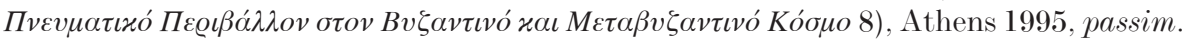

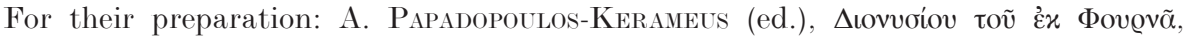

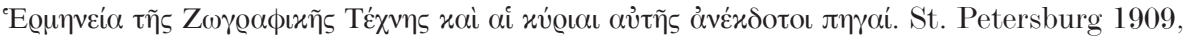

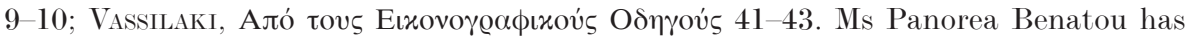
completed her MA dissertation with the title: Working Drawings of Post-Byzantine Artists. The case of Damaskinos and Tzanes. Courtauld Institute of Art, University of London 2001.

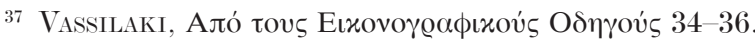


the other on Patmos painted by Ritzos, offer the visual proof of this exchange. ${ }^{38}$ Similarly, Thomas Vathas or Batas, a Cretan painter active in the last quarter of the sixteenth century, left all his works (including his anthibola) to his apprentice, Manuel Tzafournaris (1570-1631) a painter from Corfu. ${ }^{39}$

The small, portable size of the British Museum icon suggests its private use by an individual or a family, who either commissioned it from its painter, or bought it from a merchant. Although Haustein-Bartsch seems to suggest so, ${ }^{40}$ the fact that the open scroll bears Greek writing does not necessarily imply that the owner was Greek. Greek was often the choice of hellenized westerners, as, for example, in the case of John Despelo, the Veneto-cretan donor of the Deesis icon on Corfu, signed by Zafuris. ${ }^{41}$ Indeed, according to Chatzidakis, the texts on icons depicting the Virgin and Child in general are usually in Greek. ${ }^{42}$ Therefore, the possibility of its owner being a Westerner is plausible, and should not be dismissed.

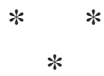

The choice of a pine panel for our icon, although not as popular as cypress in Cretan production, finds parallels in a number of icons from the island and, therefore, does not contradict an origin in Crete. ${ }^{43}$ The fact that the type of the Madre della Consolazione to which the British Museum icon belongs was introduced and became popular on the island from the second half of the fifteenth century onwards, suggests that its creation and popularity is closely connected to Crete's social circumstances of the period.

38 Angelos: Acheimastou-Potamianou (ed.), From Byzantium to El Greco 101, 168 (no. 33);

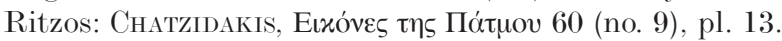

39 Chatzidakis, Eıxóves тᄁৎ Пótuov 109, 161. By 1586 Vathas was already living in Corfu. He died in 1599 in Venice.

${ }^{40}$ Haustein-Bartsch, Eine neuentdeckte Ikone 140.

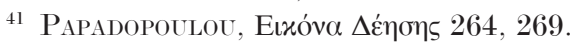

42 Chatzidakis, Débuts 202. A better indication that a work of art was destined for the Latin-speaking market is usually provided by the Latin signature of the artist: for example, the icon depicting the Crucifixion in the National Gallery of Athens bears the signature ANDREAS PAVIAS PINXIT DE CANDIA (Andreas Pavias from Chandakas painted this). This artist of the second half of the fifteenth century also signed some of his works in Greek: Chatzidakis, Débuts 188-195, pl. KA 1, 2; Chatzidakis, Essai sur l'école 90-98, figs. 68, 69 (details).

${ }^{43}$ Buckton (ed.), Byzantium 215. I would like to thank Mr L. Morroceo who confirmed the use of pine wood in Cretan icon production. 
Crete was under Venetian domination between the years 1211 and 1669 . Until recently it was generally accepted that up until the fall of Constantinople in 1453 Cretans considered themselves the moral subjects of Byzantium and were hostile towards their conquerors. ${ }^{44}$ It is true that the Venetians had to deal with at least twelve major uprisings during the first years of occupation..$^{45} \mathrm{It}$ is also true that eleven inscriptions found in Cretan Orthodox churches and dated between the years 1291 and 1446 refer to the Palaiologan emperors as if they were still the rulers of the island. ${ }^{46}$ The one and only inscription which refers to the Venetians as "great" and "our (i.e. Crete's) masters" is exceptional and unique for the island: it is found in the church of the Archangel Michael at Kavalariana Kandanou, and it is dated by inscription $1327 / 28 .{ }^{47}$ It cannot be argued that the fall of Constantinople in 1453 lifted any remaining barriers to western-eastern cultural fusion and peaceful co-existence. However, today we have enough political, cultural and artistic evidence to support the suggestion that this process had started well before the loss of the Byzantine Empire.

For example, in 1363 the native population of Crete joined forces with Venetian colonists and rebelled against the increasing demands of the central government in Venice. ${ }^{48}$ While the Metropoly defeated the uprising of Saint Titos - as the rebellion is known - in 1367, the important point here is that, from a political point of view, by the fourteenth century the Cretan and Venetian inhabitants of the island had developed common interests, strong enough to unite them against Venetian authority based outside Crete.

${ }^{44}$ Chatzidakis, Essai sur l'école 73; S. Kalopissi-Verti, Dedicatory Inscriptions and Donor Portraits in Thirteenth-Century Churches of Greece (VTIB 5). Vienna 1992, 25; N. PSI-

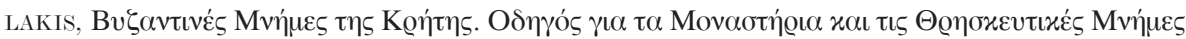

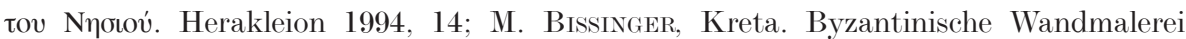
(Münchener Arbeiten zur Kunstgeschichte und Archäologie 4), Munich 1995, 21 and n. 5, 6; Ch.A. Maltezou, Byzantine 'consuetudines' in Venetian Crete. DOP 49 (1995) 269-280 (279-280).

${ }^{45}$ Ch. Maltezou, The Historical and Social Context, in: Literature and Society in Renaissance Crete (ed. D. Holton). Cambridge-New York-Port Chester-Melbourne-Sydney 1991, 17-47 (23-25). See also Lymberopoulou, Kavalariana 8-11.

${ }^{46}$ Lymberopoulou, Kavalariana 255-259.

47 Lymberopoulou, Kavalariana 254-255 and passim.

48 J. Jegerlehner, Der Aufstand der kandiotischen Ritterschaft gegen das Mutterland

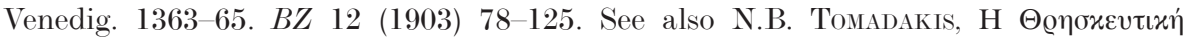

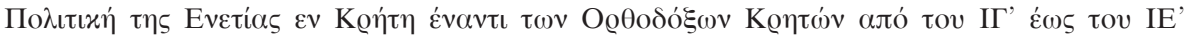

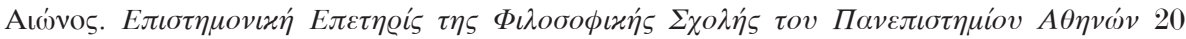

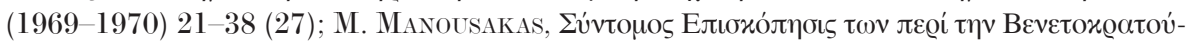

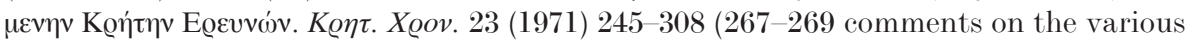


By the fourteenth century the Cretans were living in cities which were designed, built and fortified according to Italian practices - and taste. The native population became familiar with western gothic and renaissance styles as well as with western religious art, which they would have been able to see in Latin churches found all over the island, well before $1453 .^{49}$ As is apparent from the garments seen in portraits of donors in Orthodox churches, the Cretans developed a taste for western fashion, ${ }^{50}$ and they were involved in business transactions with the Latins. ${ }^{51}$ Intermarriages between Latin and Greeks at all levels of the social hierarchy are mentioned in the sources already from the thirteenth century. ${ }^{52}$ Despite the fact that the official language in the island was Latin, ${ }^{53}$ the bilingualism of Venetian settlers is noted from the early fourteenth century as in the case, for example, of Stefano Bon, one of the most important notaries in Candia,

bibliography written about the rebellion); P. Topping, Co-Existence of Greeks and Latins in Frankish Morea and Venetian Crete, in: Studies on Latin Greece A.D. 1205-1715.

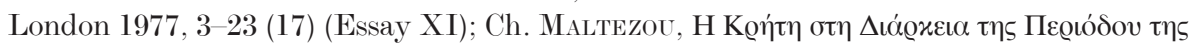

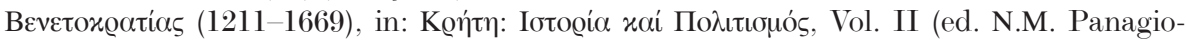
takis). Herakleion 1988, 105-161 (125-126); D. J АсовY, Social Evolution in Latin Greece, in: A History of the Crusades, Vol. VI (eds. H.W. Hazard and N.P. Zacour). Madison - Wisconsin 1989, 175-221 (204); Maltezou, The Historical and Social Context 24-25; S. McKee, Uncommon Dominion. The Latins and Greeks of Fourteenth-Century Venetian Crete (A thesis submitted in conformity with the requirements for the degree of Doctor of Philosophy). Centre for Medieval Studies, University of Toronto 1992, 144-179; M. Georgopoulou, Late Medieval Crete and Venice: An Appropriation of Byzantine Heritage. Art Bulletin 77 (1995) 479-496 (486).

${ }^{49}$ For the Venetian fortifications in the island: G. Gerola, Monumenti veneti nell'isola di Creta I (R. Istituto Veneto di Scienze, Lettere ed Arti). Venice 1905/06; for public and governmental buildings: G. Gerola, Monumenti veneti nell'isola di Creta III (R. Istituto Veneto di Scienze, Lettere ed Arti). Venice 1917, 9-142 and G. Gerola, Monumenti veneti dell'isola di Creta IV (R. Istituto Veneto di Scienze, Lettere ed Arti). Venice 1932, 9-282; for the Latin churches: G. Gerola, Monumenti veneti nell'isola di Creta II $(R$. Istituto Veneto di Scienze, Lettere ed Arti). Venice 1908, 17-169. See also M. VassilakisMavrakakis, Western Influences on the Fourteenth Century Art of Crete. JÖB 32/5 (1982) 301-311 (302); Georgopoulou, Late Medieval Crete 481-483.

${ }^{50}$ Lymberopoulou, Kavalariana 278-281.

51 Topping, Co-Existence 19; Maltezou, H Kov́tᄁ 140; Jacoby, Social Evolution 217.

${ }^{52}$ A. E. LAiou, Quelques Observations sur l' Économie et la Société de Crète Vénitienne (ca. 1270-ca. 1305), in: Bisanzio e l' Italia. Raccolta di Studi in Memoria di Agostino Pertusi (Scienze Filologiche e Letteratura 22). Milan 1982, 177-198 (197-198); JAсовY, Social Evolution 202-205; MaLtezou, The Historical and Social Context 33.

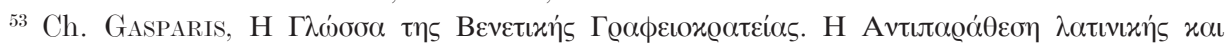

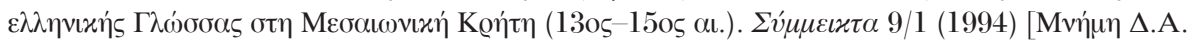
Zaxvөๆvoú] 141-156. 
and probably an offspring of mixed marriage ${ }^{54}$ eventually, by the sixteenth century, the Cretan dialect was predominant. ${ }^{55}$ The thorny issue of religion was aggravated by a strict Venetian policy, which took the property from the Orthodox Church in the island, banished many Orthodox bishops, and forbade the ordination of Orthodox priests. ${ }^{56}$ However, the shortage of Latin priests on Crete, which led the Catholic inhabitants of the island to attend Orthodox services, and the Serenissima's position 'semo Veneziani e poi Christiani' (we are first Venetians and then Christians), did not efface, but certainly decreased, the gap between the faithful of the two churches. ${ }^{57}$

The obvious and predominant 'Byzantine' character of the art in Crete did not stop the appearance of western influences as early as the fourteenth century. The inclusion of soldiers dressed in western uniforms, most often encountered in the scenes of the Betrayal, the Bearing of the Cross, the Crucifixion, the Holy Women at the Tomb, and the martyrdom of saints, is very common - albeit, in these cases, it may symbolize evil, since it is restricted to figures, who one way or another, added to Christ's or to the saints' suffering. ${ }^{58}$ Less potentially weighed evidence also appears, however. In the fresco depicting the Last Supper in the church of the Panagia Kera, outside Kritsa in Merambello, dated in the late thirteenth or early four-

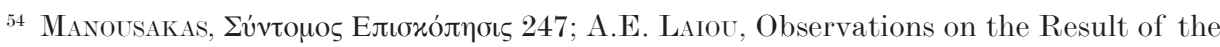
Fourth Crusade: Greeks and Latins in Port and Market. Medievalia et Humanistica 12 (1984) 47-60 (53, 54); A.E. LAIou, Venetians and Byzantines: Investigation of Forms

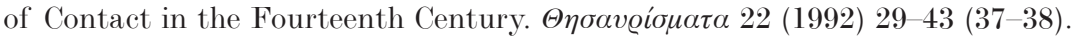

55 Maltezou, The Historical and Social Context 33-35.

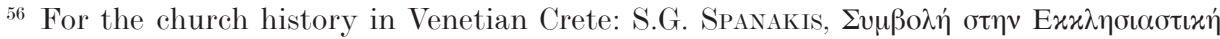

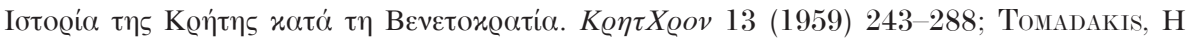

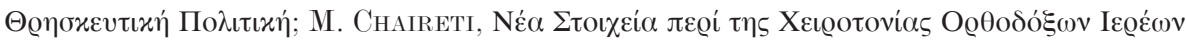

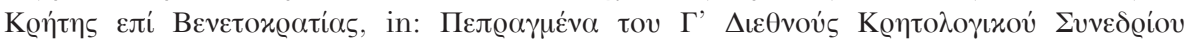

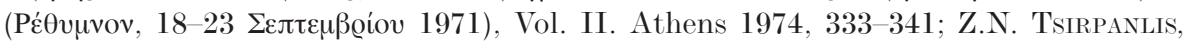

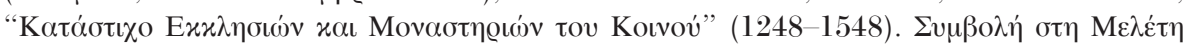

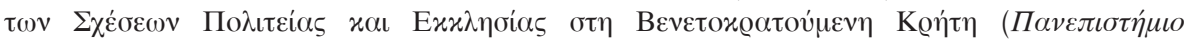

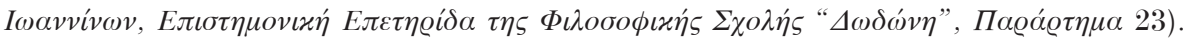
Ioannina 1985; Maltezou, The Historical and Social Context 26-29.

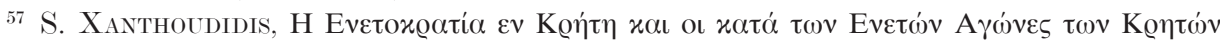
(Texte und Forschungen zur Byzantinisch-Neugriechischen Philologie 34). Athens 1939,

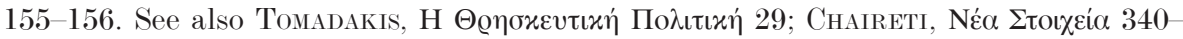
341; Maltezou, The Historical and Social Context 34. Venice tried to prevent the attending of Orthodox services by Catholics, by issuing decrees in 1349 and 1405: JACOBY, Social Evolution 205-206. However, the renewal of the first decree by the latter implies that the Catholics did not give up the attendance of the Orthodox services.

58 Lymberopoulou, Kavalariana 263-264. 
teenth century, we have Venetian elements in the layout of the table, which can be regarded as evidence of the day-to-day interaction between the two groups. ${ }^{59}$ The radiating halo in relief, widely used in Italian painting from the second half of the thirteenth century onwards, ${ }^{60}$ is also encountered in fourteenth-century Cretan painting (e.g. in the fresco depicting the Chairete, in the church of the Katholikon at Balsamonero, Kainourjio, dated in the second half of the fourteenth century). ${ }^{61}$ Saints belonging to the Latin Church are depicted in Byzantine churches among Orthodox saints: for example, Saint Francis of Assisi was a saint particularly loved by the Cretans. ${ }^{62}$ Another example of the adoption of western iconography by the Cretans is offered by two fresco representations of Saint Bartholomew dated to the fourteenth century, one in Hagia Pelagia at Viannos and the other in Hagioi Apostoloi at Drys: in both churches the saint is depicted holding his flayed skin, following the western tradition of his martyrdom (according to the Orthodox Church he was crucified). ${ }^{63}$ The fresco depicting the enthroned God the Father holding in his arms the Cross with the crucified Christ in the church of the Panagia and Sotiros Christou at Roustika, dated 1381/82, follows a western iconographic variation of the scene known as "Thronum Gratiae" - or "Throne of Mercy" - depicted in the West from the beginning of the twelfth century. ${ }^{64}$ Following this path, the unlimited

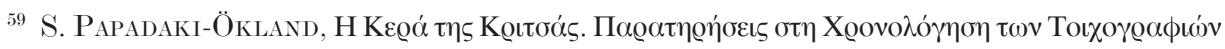

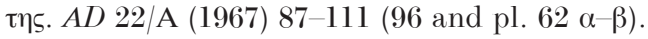

${ }^{60}$ For example, the frescoes in the upper church of Saint Francis at Assisi by Cimabue, dated in the 1280 's: M. Chiellini, Cimabue. Florence 1988, figs. 21-26, 38-44, 46-53, and 55-56.

61 Bissinger, Kreta fig. 144. See also Vassilakis-Mavrakakis, Western Influences 303.

62 Saint Francis is included in two fourteenth-century programmes: in the church of the Panagia Kera at Kritsa, and in the church of the Panagia at Sambas, Pediada. Kritsa:

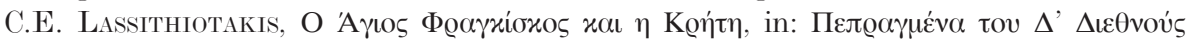

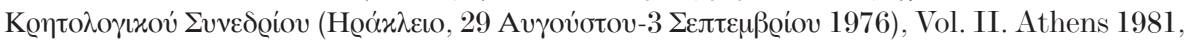

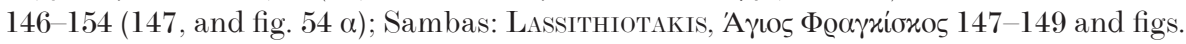
55, 56, and M. Borboudakis, K. Gallas and K. Wessel, Byzantinisches Kreta. Munich 1983, 118, fig. 69. For the popularity of Saint Francis in Crete: Lassithiotakis, Ayıos

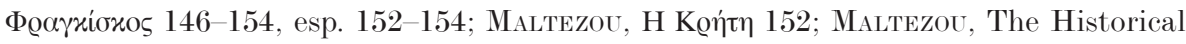
and Social Context 34 .

63 Vassilakis-Mavrakakis, Western Influences 304, figs. 7 and 8. For the martyrdom of Saint Bartholomew and its representation in the Orthodox and Catholic Churches: A.

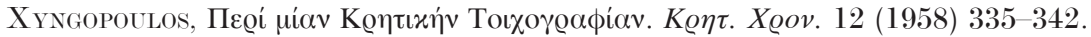

64 Borboudakis, Gallas, and Wessel, Byzantinisches Kreta 119, fig. 70, and I. SpathaRAKIS, Byzantine Wallpaintings of Crete. Rethymnon Province I. London 1999, pl. 19b and fig. 242. For the subject: R. Schiller, Ikonographie der christlichen Kunst II. Gütersloh 1968, 133-136, figs. 411-414, 425. For a discussion on the Roustika representation and its relation to the Italian art of the thirteenth and fourteenth centuries see the unpub- 
use of Italian motives in post-Byzantine art, as exemplified by the art of one of its most famous representatives, Michael Damaskinos (1530/35$1592 / 93)$, is not surprising. ${ }^{65}$

Based on the above, it is evident that the fusion between the two different civilizations had started well before 1453. Within this political and social context, the popularity of an icon type such as the Madre della Consolazione is self-explanatory. Cretans and Latins were exposed to each other's culture for centuries. The Cretans, as mentioned above, developed a notable taste for western fashion, as attested in church decoration. ${ }^{66}$ This is also evident from preserved documents, which tell us that dressmakers in the capital of the island, Candia, created clothes according to the western fashion for their clients, while from the fifteenth century onwards, wealthy women ordered their garments directly from Venice. ${ }^{67}$ Adopting an icon that showed the Virgin and Child dressed in the western fashion would not have been a difficult process. On the other hand, western culture was familiar with the Byzantine type of the Virgin and Child, the Virgin Hodegitria, introduced in Italy about $1100,{ }^{68}$ which was adopted and adapted in Italian soil by painters such as Coppo di Marcovaldo and Guido da Siena. ${ }^{69}$ Furthermore, Venice on two separate occasions embraced and adopted the cult of Byzantine icons: one was the Virgin Nikopoia, brought to Venice after the sack of Constantinople in 1204, and displayed on the high altar in San Marco on solemn feast days and at times when the city was in danger $;^{70}$ the other was the Virgin Mesopanditissa, firstly adopted

lished MA Dissertation: A.D. Dile, The Anthropomorphic Holy Trinity in Byzantine and Post-Byzantine Art. Courtauld Institute of Art, University of London 1998, 2628. Spatharakis, Byzantine Wallpaintings 198-206, 271, suggested that the church was converted to Catholicism.

${ }^{65}$ Chatzidakis, Débuts 205; Chatziddakis, Essai sur l'école 115. For Damaskinos: ChatziDaKis, 'E $\lambda \lambda \eta v \varepsilon \varsigma$ Z $\omega \gamma \varrho \alpha ́ \phi o r ~ 241-253$. See also the unpublished Ph.D thesis: M. Konstan-

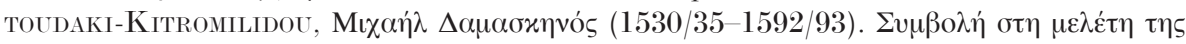

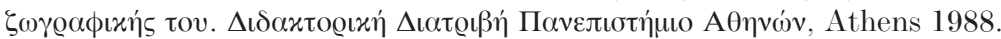

${ }^{66}$ See supra, note 50.

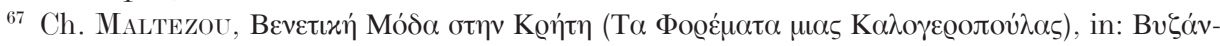

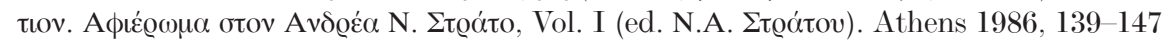

${ }^{68}$ V. Pace, Between East and West, in: Mother of God. Presentations of the Virgin in Byzantine Art, Benaki Museum 20 October 2000-20 January 2001 (ed. M. Vassilaki). Athens 2000, 425-432 (425-426).

${ }^{69}$ See supra, note 27.

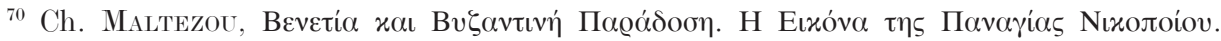

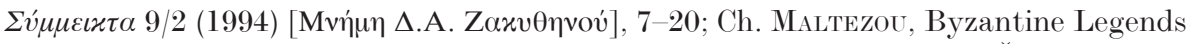
in Venetian Crete, in: AETO $\Sigma$. Studies in Honor of Cyril Mango (eds. I. Ševčenko and I. Hutter). Stuttgart-Leipzig 1998, 233-242 (237-2390). 
by the Venetians from the local Cretan culture, and eventually, when Candia was lost to the Turks, brought to Venice in 1672 where it was placed in the church of Santa Maria della Salute. ${ }^{71}$ As noted above, because of the shortage of Catholic priests on the island, Creto-Venetians attended Orthodox services, and were therefore familiar with Orthodox church surroundings and practices: ${ }^{72}$ in the second volume of his Monumenti Veneti Nell'Isola di Creta, Gerola wrote that every Venetian family had an icon..$^{73}$ The latter statement is exemplified in a painting by Carpaccio, depicting Saint Ursula talking to her father and dated in the mid 1490's: on the wall there is an icon depicting the Virgin and Child, very similar to the Madre della Consolazione type, though the Child here is naked. ${ }^{74}$ The popularity of the type during the post-Byzantine period coincides with the appreciation of icons and, therefore, their vast demand in the artistic market, attested in documents. For example, according to contracts dated 1499, two merchants, one from Venice, the other from the Peloponnese, commissioned seven-hundred icons of the Virgin from three Cretan painters, to be delivered within forty-five days. ${ }^{75}$ The contracts state that two-hundred had to be painted a la greca (in the Greek manner) the rest five-hundred a la latina (in the Italian manner), and for a number of them specific requests are made for the colour of the Virgin's mantle (either turquoise or purple). ${ }^{76}$ Chatzidakis is of the opinion that the clause a la latina in such documents implies the Madre della Consolazione type. ${ }^{77}$ Be that as it may, these contracts - and others of the same nature - are very important. Firstly, they state the price, therefore inform us about the market price for portable

${ }^{71}$ Georgopoulou, Late Medieval Crete 487-490. See also A. Chastel, Medietas imaginis. Le prestige durable de l'icône en Occident. CahArch 36 (1988) 99-110 (106).

72 See supra, note 57.

${ }^{73}$ Gerola, Monumenti II 312.

${ }^{74}$ J. Lauts, Carpaccio. Paintings and Drawings. Complete edition. London 1962, pls. 40, 45. Gouma-Peterson, Creto-Venetian Icon 71, n. 54, believes that the inclusion of the icon in Carpaccio's canvas painting (not fresco, as Gouma-Peterson refers to it) is symbolic rather than indicative of Venetian households. However, the attention to detail that the painter has paid in his cycle of Saint Ursula (i.e. depiction of architectural settings and sculpture that decorates indoors and outdoors settings; LAUTs, Carpaccio pls. 18, 22) offers a counter argument to Gouma-Peterson's suggestion.

75 Cattapan, Nuovi elenchi 211-213 (nos.6-8), 214-215. See also Vassilaki, Aтó tov

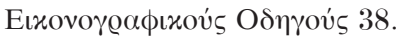

76 “...ymago de la nostra Dona no cento de prima sorta, la mità con vestimenti de turchin brocà d'oro et l'altra mità color de pavonaço brocà d'oro segondo la forma del la mostra...": CatTapan, Nuovi elenchi 212.

77 Chatzidakis, La peinture des 'Madonneri' 688. 
icons in the year $1499 .{ }^{78}$ Secondly, they imply a co-operation between the Cretan workshops in order to respond to such vast commissions in so short a time. Thirdly, they point to the ability as well as the obligation of the Cretan post-Byzantine painters to know how to paint in both in forma a la greca and in forma a la latina in order to cope with the demands of their clientele, ${ }^{79}$ and to survive the increasing competition in their field.$^{80}$ Fourthly, they prove the existence of a market in the late fifteenth century with great demand for and focus on icons. Set against this information, the popularity of the Madre della Consolazione that coincides in time with the boost of an icon market is better understood.

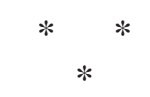

The sixteenth-century Madre della Consolazione icon of the British Museum belongs to a hybrid type of the Virgin and Child, a product of a hybrid society. Centuries of co-existence between Greeks and Latins, Orthodox and Catholics on Crete, the most precious possession of Venice in the Mediterranean between 1211 and 1669, ${ }^{81}$ led to the - inevitable - fusion of eastern and western culture. As a consequence, the society created on Crete was receptive to elements of two cultures. The introduction of the Madre della Consolazione type in the second half of the fifteenth century, and its distribution until the seventeenth century, is a testimony to a thriving icon market, but also a reflection and manifestation of the hybrid society that conceived and embraced it.

${ }^{78}$ For the prices and evaluation of the icons in the sixteenth and seventeenth centuries:

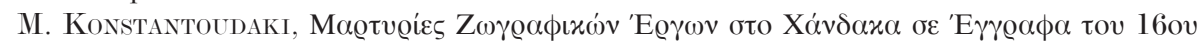

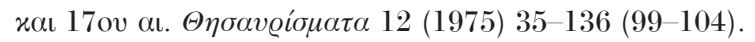

${ }^{79}$ Chatzidakis, La peinture des 'Madonneri' $675,680$.

${ }^{80}$ A number of documents testify for the increasing number of painters in Candia between

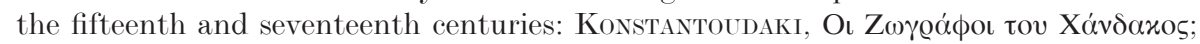

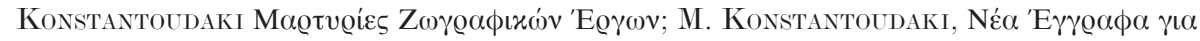

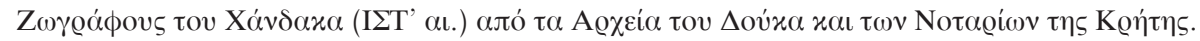

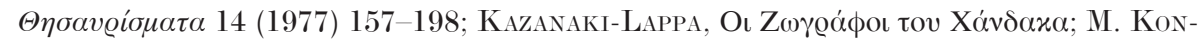

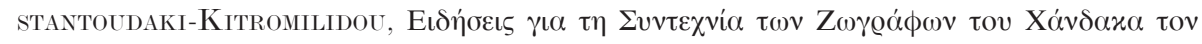

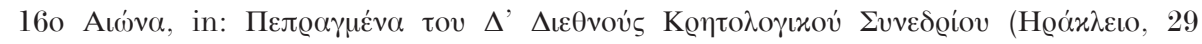

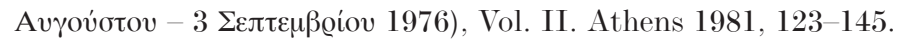

${ }^{81}$ Laiou, Venetians and Byzantines 34. 
